\title{
Incidence of Human Cytomegalovirus in Breast Carcinoma Tissues is Associated with A Higher Expression of Growth Factor Receptor-Bound Protein 2 Mohamed Fares $^{1 *}$, Hossam Taha Mohamed ${ }^{2,3}$, Sherif Abdelaziz Ibrahim ${ }^{3}$, Mohamed Hosney ${ }^{3}$, Mohamed I. Rady ${ }^{1}$, Mohamed El-Shinawi ${ }^{4}$, Mona Mostafa Mohamed ${ }^{3}$ \\ ${ }^{1}$ Department of Zoology, Faculty of Science, Al-Azhar University, Cairo, ${ }^{2}$ Faculty of Biotechnology, October University for Modern Sciences and Arts, Giza, ${ }^{3}$ Department of Zoology, Faculty of Science, Cairo University, \\ ${ }^{4}$ Department of General Surgery, Faculty of Medicine, Ain Shams University, Egypt \\ *Corresponding author: Mohamed Fares, Tel: +2-01113074575, Email: moh.fares@azhar.edu.eg and moh.fares.sci@gmail.com
}

\begin{abstract}
Background: female mammary carcinoma is the second most common cancer incidence among women and the fifth most common leading cause of cancer death worldwide. Premenopausal young women are more frequently targeted by inflammatory breast cancer (IBC), which is the most lethal form of breast cancer. The human cytomegalovirus (HCMV) has been identified as one of the viral infection with a higher frequency in carcinoma tissues of IBC than in non-IBC. The adaptor protein growth factor receptor-bound protein 2 (Grb2), was found to be upregulated in HCMV-infected cells and play as crucial role in cancer progression.

Objective: this study aimed to assess the expression level of Grb2 in carcinoma tissues of IBC and non-IBC with HCMV infection.

Patients and Methods: overall, 135 female diagnosed with breast carcinoma were enrolled in this study. Using conventional and real time polymerase chain reaction (PCR), we determined the incidence of HCMV and assessed the expression level of Grb2 mRNA in the breast cancer tissue samples.

Results: Grb2 mRNA was significantly upregulated in $\mathrm{HCMV}^{+} \mathrm{IBC}$ higher than in $\mathrm{HCMV}^{+}$non-IBC. According to the molecular subtype, Grb2 mRNA was significantly higher upregulated in breast carcinoma tissues of $\mathrm{HCMV}^{+}$ hormonal positive (HP) than in triple negative (TN) counterparts.

Conclusion: HCMV infection is associated with a high expression of Grb2 mRNA in IBC and that HP HCMV ${ }^{+}$ mammary carcinoma tissues confer upregulated Grb2 mRNA, suggesting a potential role of HCMV infection in enhancing of Grb2 mRNA expression in breast cancer with HP.
\end{abstract}

Keywords: Growth factor receptor-bound protein 2, human cytomegalovirus, inflammatory breast cancer.

\section{INTRODUCTION}

Breast cancer is the most prevalent cancer among Egyptian women and comprises approximately $29 \%$ according to National Cancer Institute (NCI) ${ }^{(1)}$. The most lethal form of breast cancer is inflammatory breast cancer (IBC), which targets young women. IBC represents about $2.5 \%$ of newly diagnosed breast cancers in the United States ${ }^{(2)}$ and its incidence is higher among African-American compared to white women ${ }^{(3)}$. IBC frequency in North African countries such as Tunisia, Morocco, and Egypt represents about $10 \%$ to $15 \%$ of breast cancer (4). Recent study conducted by Schairer and colleagues at the National Cancer Institute, Egypt, and at Institute Salah Azaiz (ISA), Tunisia, suggests that the increase of IBC cases in North Africa may be due to misdiagnosis of IBC with other types of locally advanced breast cancer ${ }^{(\mathbf{5})}$.

There are several signaling molecules which are overexpressed in human breast cancer, such as growth factor receptor-bound 2 (Grb2). The role of Grb2 as a signal transducer for several oncogenic growth factor receptors and the involvement of Grb2 in multiple steps of the metastasis cascade, therefore emerging as a target for antitumor therapeutic strategies ${ }^{\left({ }^{(}\right)}$. Grb2 serves as an adaptor protein for a variety of cellular functions and acts as a critical downstream intermediary in several oncogenic signaling pathways ${ }^{(7)}$.

Human cytomegalovirus (HCMV) is an oncomodulatory virus that has been found to be involved in breast cancer ${ }^{\left({ }^{8}\right)}$.

Grb2 as a cytoplasmic adaptor protein that associated with activated epidermal growth factor receptor (EGFR) has a functional contribution during viral replication and pathogenesis ${ }^{(9)}$. While more than 70 cellular proteins were found to be associated with HCMV virion (the infective form of a virus outside a host cell) ${ }^{(\mathbf{1 0}, \mathbf{1 1})}$, little is known about their role during viral replication cycle.

\section{AIM OF THE WORK}

This study aims to examine whether the expression of Grb2 mRNA patients correlated with incidence of HCMV infection in carcinoma tissues of IBC and non-IBC and that correlation was assessed different molecular subtypes of breast cancer.

\section{PATIENTS AND METHODS}

Patients and Samples: outpatients clinics of AinShams University hospitals from January 2015 till January 2017 which, were previously diagnosed as 
breast cancer by clinical ultrasound examination, mammography and tru-cut biopsy ${ }^{(\mathbf{1 2})}$, a total of 135 breast cancer patients (44 inflammatory breast cancer (IBC) and 91 non-IBC) and 50 healthy volunteers were enrolled in the present study, carcinoma tissues were obtained during modified radical mastectomy (MRM). Normal breast tissues were obtained from healthy volunteers undergoing mammoplasty.

Ethical and approval statements: for patients enrolment we obtained an Institutional Review Board (IRB) approval from the Ethics Committee of Faculty of Medicine, Ain Shams University, Egypt (No. IRB0006379). All enrolled healthy volunteers and breast cancer patients signed informed consent that agrees with publication of anonymous data.

\section{PCR assay for the detection of HCMV DNA in breast carcinoma tissues:}

DNA was extracted from $30 \mathrm{mg}$ fresh breast carcinoma tissues using GeneJET ${ }^{\mathrm{TM}}$ Genomic DNA purification Kit (Thermo scientific, Waltham, MA, USA). For detection of HCMV DNA, we applied nested PCR reaction using two sets of primers that specific for the fourth exon of the HCMV Immediate Early (IE) gene described by Zhang et al. ${ }^{(13)}$. Briefly, the first round of PCR was carried out in a $25 \mu$ total volume containing $1 \mu 1$ of each external upstream and downstream primers (10 pmol $\mu \mathrm{l}), 3 \mu \mathrm{l}$ of the DNA extract from fresh breast cancer tissue, $7.5 \mu$ l of free RNase water and $12.5 \mu \mathrm{l}$ of Green Taq-polymerase master mix.

Reaction conditions included an initial denaturation step of $94^{\circ} \mathrm{C}$ for $5 \mathrm{~min}$, followed by 30 cycles of $94^{\circ} \mathrm{C}$ for $45 \mathrm{sec}, 55^{\circ} \mathrm{C}$ for $45 \mathrm{sec}$, and $72^{\circ} \mathrm{C}$ for $45 \mathrm{sec}$, followed by terminal extension at $72^{\circ} \mathrm{C}$ for $10 \mathrm{~min}$. The second round of PCR was performed in the same manner as the first, but using $3 \mu \mathrm{l}$ of the first reaction as template, $1 \mu \mathrm{l}$ of each internal upstream and downstream primers $(10$ pmol $\mid \mu l)$ and an annealing temperature of $50^{\circ} \mathrm{C}$ for $45 \mathrm{sec}$. After nested PCR amplification, $10 \mu \mathrm{l}$ of PCR products were electrophoresed on $2 \%$ agarose gel stained with ethidium bromide, and photographed by the GBOXF3 gel documentation system Syngene (Syngene, MD, USA).

All PCR amplifications were conducted using sterilized tubes and tips in a biosafety hood that was not previously exposed to HCMV. Controls without breast tissues tested negative, affirming the lack of contamination.

Quantitative real-time PCR: total RNA was extracted from $30 \mathrm{mg}$ of each fresh breast tissue sample using GeneJET ${ }^{\mathrm{TM}}$ RNA Purification Kit (Thermo scientific, ON, Canada). RNA concentration was measured and $1 \mu \mathrm{g}$ transcribed into complementary DNA using RevertAid First Strand cDNA Synthesis Kit (Thermo scientific, ON, Canada). Quantitative PCR was performed via using Step one plus 96well device (Applied Biosystems) and in a $25 \mu \mathrm{l}$ total volume using $12.5 \mu \mathrm{l}$ SYBR green master mix (Applied Biosystems, Brumath, France), $0.5 \mu 1$ of each GRB2 of each upstream 5CTCCCTCTCTGTCAAGTTTGGA-3 ${ }^{\prime}$ and downstream 5'- AGTACTTCCCGGCTCCATCT-3` primers $(10 \mathrm{pmol} / \mu \mathrm{l}), 2.5 \mu \mathrm{l}$ of $\mathrm{cDNA}$ and $8 \mu \mathrm{l}$ of RNase free water. Reaction thermal profile started with initial denaturation at $95 \square \mathrm{C}$ for $10 \mathrm{~min}$, then followed by 45 cycle of $94 \square \mathrm{C}$ for $15 \mathrm{sec}$ and $60 \square \mathrm{C}$ for $1 \mathrm{~min}$. Amplification specificity was confirmed using melting curve analysis and 2\% agarose gel electrophoresis of the PCR products. Data were analyzed using the $2^{-\Delta \Delta \mathrm{Ct}}$ method after normalization to glyceraldehyde 3-phosphate dehydrogenase (GAPDH) (Qiagen, USA.) (10pmol/ $\mu \mathrm{l})$.

Statistical Analysis: data were expressed as mean ( \pm ) standard deviation (SD). Statistical difference between groups was assessed by Student's t-test and Chi square test. $P$ values $<0.05$ were considered to be statistically significant using SPSS 22.0 software.

\section{RESULTS}

Clinical and pathological characterization of breast cancer patients: clinical and pathological characterization of non-IBC and IBC patients was described in (Table 1).

Statistical analysis showed that IBC patients were characterized with significantly larger tumor size ( $p=$ 0.003 ) in comparison with non-IBC patients. Moreover, the status of lymph node metastasis and lymphovascular invasion in IBC patients was significantly higher $(p=0.002$ and 0.001, respectively) than non-IBC patients. 
Table 1: Clinical and pathological characterization of non-IBC versus IBC patients

\begin{tabular}{|c|c|c|c|}
\hline Characteristic & $\begin{array}{l}\text { Non-IBC } \\
(\mathbf{N}=91)\end{array}$ & $\begin{array}{c}\text { IBC } \\
(\mathrm{N}=44)\end{array}$ & $P$ value \\
\hline \multicolumn{4}{|l|}{ Age (year) } \\
\hline $\begin{array}{l}\text { Range } \\
\text { Mean } \pm \text { SD } \\
\text { NA }\end{array}$ & $\begin{array}{c}27-78 \\
51.98 \pm 10.969 \\
1\end{array}$ & $\begin{array}{c}29-72 \\
49.34 \pm 11.994 \\
0\end{array}$ & $0.223^{\mathrm{a}}$ \\
\hline \multicolumn{4}{|l|}{ Tumor Size $(\mathrm{cm})$} \\
\hline $\begin{array}{l}\text { Mean } \pm \text { SD } \\
\leq 4 \\
>4\end{array}$ & $\begin{array}{c}4.6 \pm 3.5 \\
58(63.7 \%) \\
33(36.3 \%)\end{array}$ & $\begin{array}{l}5.73 \pm 2.71 \\
16(36.4 \%) \\
28(63.6 \%)\end{array}$ & $0.003^{* a}$ \\
\hline \multicolumn{4}{|l|}{ Pathology } \\
\hline $\begin{array}{l}\text { Ductal Carcinoma In Situ } \\
\text { Invasive Ductal Carcinoma } \\
\text { Invasive Lobular Carcinoma } \\
\text { NA }\end{array}$ & $\begin{array}{c}10(11.0 \%) \\
73(81.2 \%) \\
7(7.7 \%) \\
1(1.1 \%)\end{array}$ & $\begin{array}{c}0(0 \%) \\
41(93.2 \%) \\
3(6.8 \%) \\
0(0 \%)\end{array}$ & $0.069^{\mathrm{a}}$ \\
\hline \multicolumn{4}{|l|}{ Tumor grade } \\
\hline $\begin{array}{l}\text { G1 } \\
\text { G2 } \\
\text { G3 }\end{array}$ & $\begin{array}{c}4(4.4 \%) \\
73(80.2 \%) \\
14(15.4 \%)\end{array}$ & $\begin{array}{c}0(0 \%) \\
35(79.5 \%) \\
9(20.5 \%)\end{array}$ & $0.304^{\mathrm{b}}$ \\
\hline \multicolumn{4}{|c|}{ Axillary Lymph Node Metastasis } \\
\hline $\begin{array}{l}\leq 4 \\
>4\end{array}$ & $\begin{array}{l}64(70.3 \%) \\
27(29.7 \%)\end{array}$ & $\begin{array}{l}14(31.8 \%) \\
30(68.2 \%)\end{array}$ & $0.002^{* b}$ \\
\hline \multicolumn{4}{|l|}{ Lymphovascular invasion } \\
\hline $\begin{array}{l}\text { Negative } \\
\text { Positive }\end{array}$ & $\begin{array}{l}75(82.4 \%) \\
16(17.6 \%)\end{array}$ & $\begin{array}{l}14(31.8 \%) \\
30(68.2 \%)\end{array}$ & $0.001^{* b}$ \\
\hline \multicolumn{4}{|l|}{ ER } \\
\hline $\begin{array}{l}\text { Negative } \\
\text { Positive } \\
\text { NA }\end{array}$ & $\begin{array}{l}35(38.5 \%) \\
38(41.8 \%) \\
18(19.8 \%)\end{array}$ & $\begin{array}{l}20(45.5 \%) \\
15(34.1 \%) \\
9(20.5 \%)\end{array}$ & $0.668^{b}$ \\
\hline \multicolumn{4}{|l|}{ PR } \\
\hline $\begin{array}{l}\text { Negative } \\
\text { Positive } \\
\text { NA }\end{array}$ & $\begin{array}{l}42(46.2 \%) \\
31(34.1 \%) \\
18(19.8 \%)\end{array}$ & $\begin{array}{l}19(43.2 \%) \\
15(34.1 \%) \\
10(22.7 \%)\end{array}$ & $0.913^{b}$ \\
\hline \multicolumn{4}{|l|}{ Her-2 } \\
\hline $\begin{array}{l}\text { Negative } \\
\text { Positive } \\
\text { NA }\end{array}$ & $\begin{array}{l}44(48.4 \%) \\
29(31.9 \%) \\
18(19.8 \%)\end{array}$ & $\begin{array}{l}21(47.7 \%) \\
13(29.5 \%) \\
10(22.7 \%)\end{array}$ & $0.915^{\mathrm{b}}$ \\
\hline
\end{tabular}

Data are reported as means \pm SD

${ }^{\text {a }}$ Student's t-test.

${ }^{b}$ Chi square test.

* Significant $p$ value $(p<0.05)$

NA = not available, $E R=$ estrogen receptor, $P R=$ progesterone receptor 
IBC patient tissues are characterized by a high frequency of HCMV-DNA compared to non-

IBC: standardized genomic DNA of peripheral blood, carcinoma and non-carcinoma tissues of nonIBC and IBC patients were subjected to nested PCR analysis for the fourth exon of the HCMV-IE gene as previously described ${ }^{(14)}$. The positive control samples were serologically determined as positive for HCMV by IgG/IgM seropositive reaction and by real time PCR for HCMV-DNA using infected patient sera, obtained from the Ain Shams University laboratory. Negative controls were obtained from peripheral blood of healthy volunteers diagnosed as HCMV-seronegative.

(A)

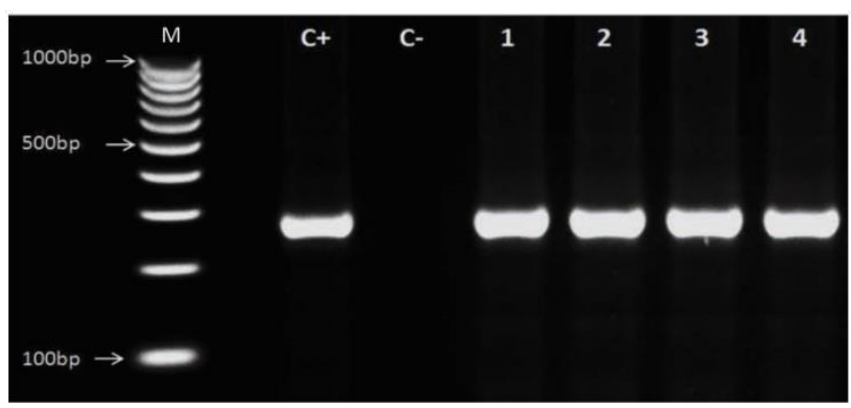

(B)

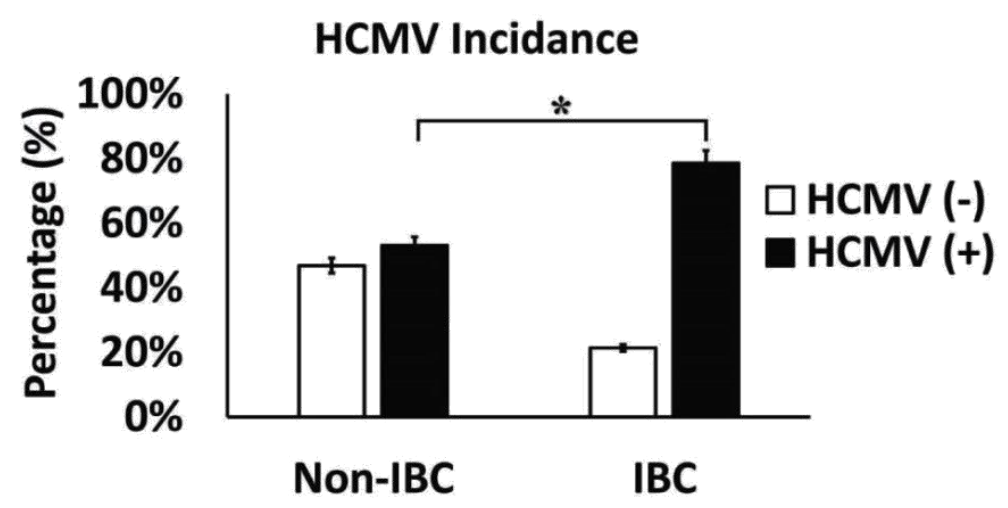

Figure (1): Incidence of HCMV DNA in breast carcinoma tissues. (A) Agarose gel electrophoresis showed HCMV DNA in non-IBC (lane $1 \& 2$ ) and IBC (lane $3 \& 4$ ) tissues. (B) Bars represent the incidence of HCMV DNA in carcinoma tissues of non-IBC and IBC patients. Data represent mean $\pm \mathrm{SD}$. * represents significant $\mathrm{p}$ value, as determined by Chi square test. 
We identified positive HCMV-DNA when agarose gel electrophoresis of PCR products revealed a band corresponding to a 293-bp DNA fragment (Fig. 1A). Using nested PCR analysis, we did not detect HCMV-DNA in peripheral blood of non-IBC and IBC patients. In contrast, PCR analysis of carcinoma tissue showed that $53.1 \%$ of non-IBC carcinoma tissues were HCMV-DNA positive and 46.9\% HCMV-DNA were negative whereas, in IBC patients $78.6 \%$ of carcinoma tissues were HCMV-DNA positive and $21.4 \%$ were HCMV-DNA negative $(P=0.030)$ (Fig. 1B).

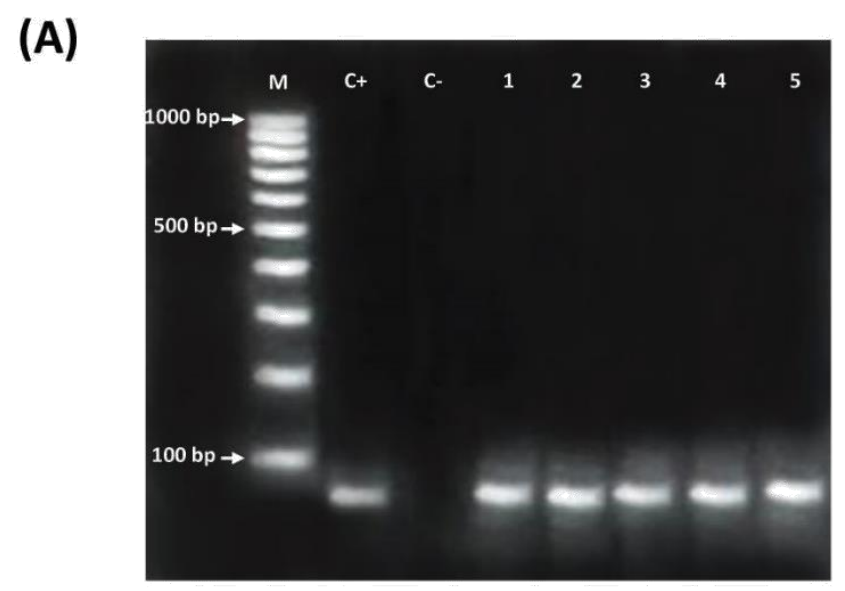

(B)

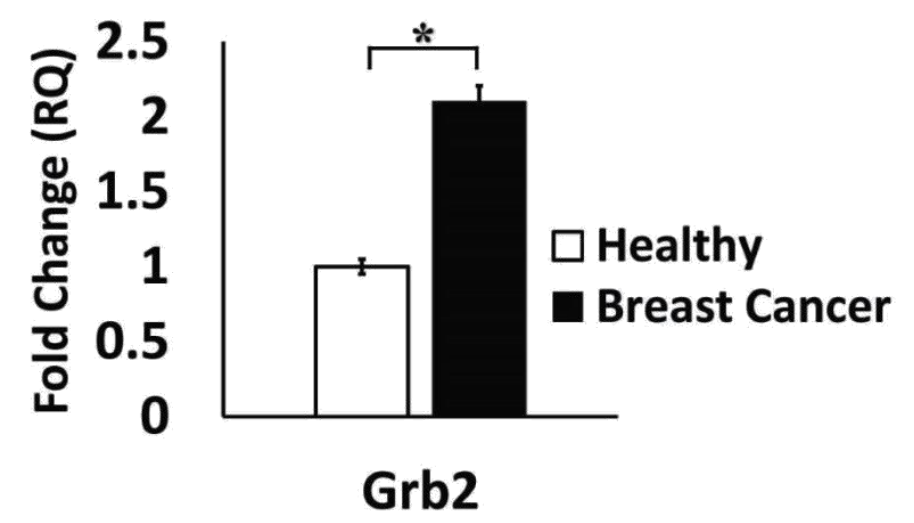

Figure (2): Grb2 mRNA expression level in breast carcinoma tissues. (A) Agarose gel electrophoresis showed Grb2 mRNA in breast carcinoma tissues (lane 1 - 5). (B) Bars represent the Grb2 mRNA expression level in healthy and carcinoma breast tissues. Data represent mean \pm $\mathrm{SD}$. * represents significant $\mathrm{p}$ value, as determined by Student's $\mathrm{t}$ test.

Grb2 mRNA is highly expressed in breast carcinoma tissues: Grb2 mRNA expression was assessed in the breast carcinoma tissues and in breast tissues of healthy volunteers. Real time PCR results showed higher expression of Grb2 mRNA in breast carcinoma tissues compared to healthy breast tissues $(P=0.01)$ (Fig. $2 \mathrm{~A} \& \mathrm{~B})$. 


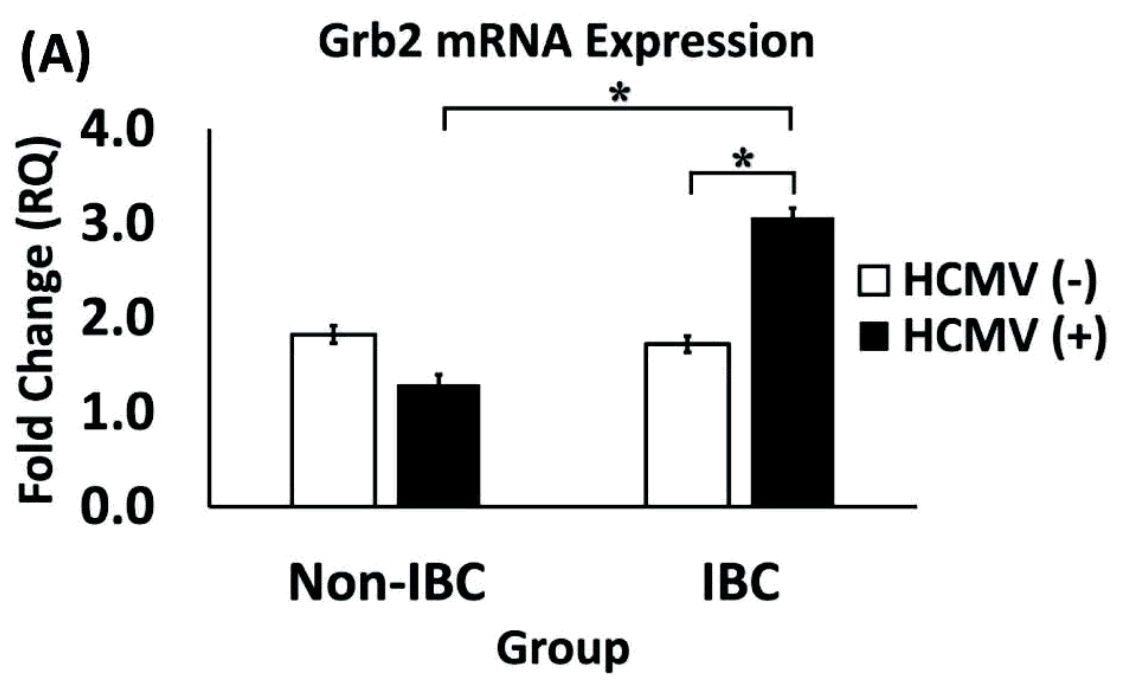

(B)

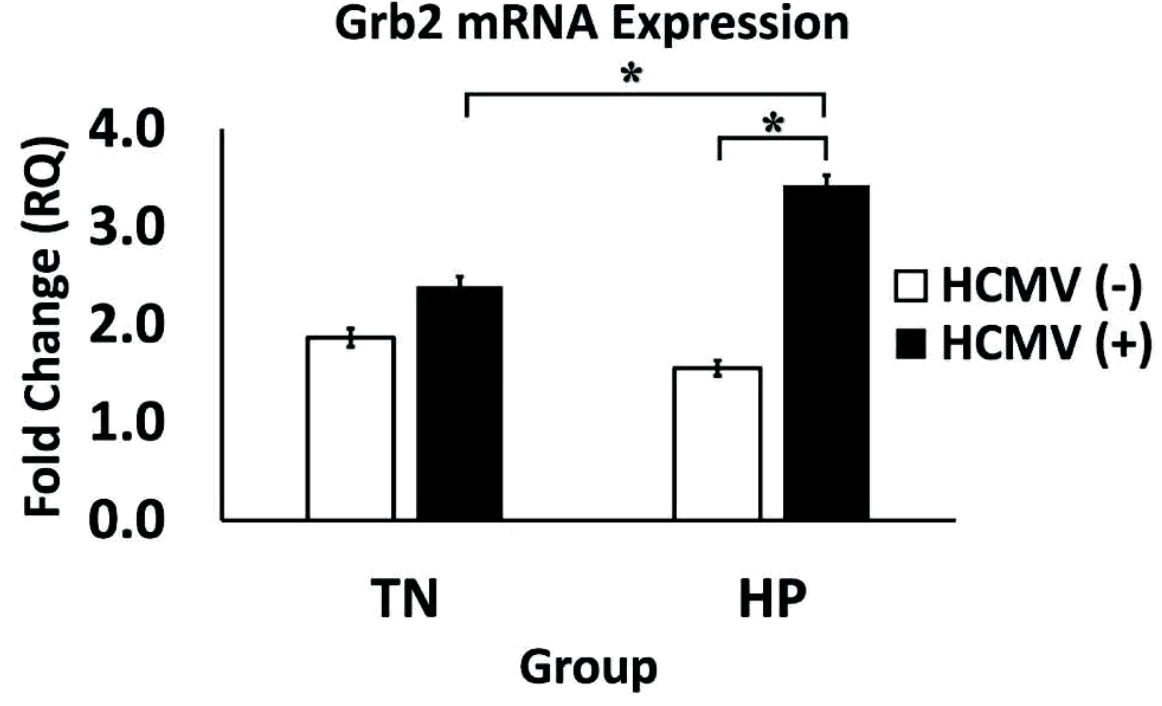

Figure (3): Grb2 mRNA expression level in breast carcinoma tissues with TN and HP molecular subtype. (A) Bars represent the Grb2 mRNA expression level in HCMV- or HCMV+ non-IBC versus IBC tissues. (B) Bars represent the Grb2 mRNA expression level in HCMV- or HCMV+ $\mathrm{TN}$ versus HP breast carcinoma tissues. Data represent mean $\pm \mathrm{SD}$. * represents significant $\mathrm{p}$ value, as determined by Student's t test.

$\mathrm{HCMV}^{+}$IBC tissues are characterized by higher mRNA expression of Grb2 compared to HCMV- IBC tissues: real time PCR results showed a higher expression of Grb2 mRNA in $\mathrm{HCMV}^{+} \mathrm{IBC}$ tissues compared to $\mathrm{HCMV}^{-} \mathrm{IBC}$ or $\mathrm{HCMV}^{+}$non-IBC tissues $(P=0.05)$ (Fig. 3A). While, there is no significant difference in the expression of Grb2 mRNA in $\mathrm{HCMV}^{-}$non-IBC tissues compared to $\mathrm{HCMV}^{+}$nonIBC or $\mathrm{HCMV}^{-}$IBC tissues (Fig. 3A).

$\mathrm{HCMV}^{+}$hormonal positive (HP) mammary carcinoma tissues are characterized by a higher Grb2 mRNA expression compared to $\mathrm{HCMV}^{+}$triple negative (TN) or $\mathrm{HCMV}^{-}$HP mammary carcinoma tissues: real time PCR results showed higher expression of Grb2 mRNA in $\mathrm{HCMV}^{+} \mathrm{HP}$ compared to $\mathrm{HCMV}^{+}$ $\mathrm{TN}$ or $\mathrm{HCMV}^{-} \mathrm{HP}$ mammary carcinoma tissues $(P=$ 0.05 ) (Fig. 3B). Whereas, there is no significant difference in the expression of Grb2 mRNA in $\mathrm{HCMV}^{-}$ $\mathrm{TN}$ compared to $\mathrm{HCMV}^{+} \mathrm{TN}$ or $\mathrm{HCMV}^{-} \mathrm{HP}$ mammary carcinoma tissues (Fig. 3B).

\section{DISCUSSION}

Different adaptor proteins are well-known for their key roles in governing the various signaling pathways. 
Grb2 connects cell membrane activated receptors to the downstream effectors mediating the basic cellular events such as cell proliferation, cell growth, and metabolism. Many recent studies have evidenced that Grb2 was largely involved in multiple malignant tumors, So, Grb2 was highly expressed in a variety of human cancers ${ }^{(15)}$, including leukemia ${ }^{(6,16)}$, human lung cancer ${ }^{(17-19)}$, esophageal squamous cell carcinoma (20), bladder cancer ${ }^{(21)}$ and mainly Grb2 overexpressed in breast cancer cell lines (MCF-7, MDA-MB-361 and $-453)$ and breast carcinoma tissue samples $(15,16,22,23)$. Our results in this study verified overexpression of Grb2 mRNA in breast carcinoma tissues relative to healthy breast tissues.

The study of viral infections and their relation with cancer risk factors may enhance the cancer treatment strategies, for example, sexually transmitted human papilloma viruses (HPV) infection where, vaccination against HPV and hepatitis B viruses (HBV) would prevent 1 million cancer cases each year ${ }^{(24)}$, where the inhibition of endogenous Grb2 led to a reduction in retrovirus infection mechanisms such as murine leukemia virus (MLV) ${ }^{(25)}$, and this supports the importance of using Grb2 inhibitors as anti-cancer drugs in cancer cases which associated with viral infection.

In humans, the viral infection like HPVs, EpsteinBarr virus (EBV), human cytomegalovirus (HCMV) and other viruses also have been recognized in human breast tumors, but there is no decisive evidence for a causal role ${ }^{(26)}$. Certain virus like HCMV may enhance the malignancy of cancer cells and/or tumor-associated cells, a paradigm the so-called oncomodulation ${ }^{(27)}$.

A deleterious inflammation is a unique character for breast cancer as tumor-associated macrophages are HCMV-infected, besides to the activation of oncogenic pathways in mammary epithelial cells ${ }^{(28)}$, and this might explain our findings that IBC tissues are characterized by a high frequency of HCMV-DNA compared to non-IBC patient tissues owing to high infiltration of tumor-associated macrophages.

HCMV is not supposed to transform the host cell itself, but HCMV-encoded proteins are contributed in cell cycle progression ${ }^{(29)}$, the infectious particles of HCMV are basically consisted of viral structural proteins including capsid, tegument and envelope proteins ${ }^{(30)}$, and in a proteomic approach, 71 cellular proteins have been informed to be involved with virions (11). One of these proteins Grb2 which its incorporation into virions dependent on the viral tegument protein pp65 of HCMV, so Cavignac et al. (31), showed that Grb2 is a proviral cellular factor that are upregulated in HCMV infected cells, this is in line with accorded with our notion of , upregulated Grb2 in carcinoma tissues of $\mathrm{HCMV}^{+} \mathrm{IBC}$ vs HCMV${ }^{-}$non-IBC.
Our results showed upregulation of Grb2 in $\mathrm{HCMV}^{+} \mathrm{IBC}$ higher than in $\mathrm{HCMV}^{-} \mathrm{IBC}$, that may explain the role of $\mathrm{Grb} 2$ in virus infected cell interactions, and this findings are agreeing with Grb2 studies with other viruses like, Cavignac et al. ${ }^{(31)}$, results in HCMV infected cell, Strunk ${ }^{(32)}$ findings in Herpes simplex virus 1 (HSV 1), Macdonald (33) investigations in Hepatitis C virus, and Rom ${ }^{(34)}$ study in HIV-1.

However, the negative correlation between highgrade expression of HCMV and hormone receptor expression in breast cancer tumors due to Rahbar $\boldsymbol{e t}$ al. (35) suggestions, our findings showed that Grb2 expressed in $\mathrm{HCMV}^{+}$hormonal positive (HP) mammary carcinoma tissues higher than in $\mathrm{HCMV}^{+}$ triple negative (TN) and $\mathrm{HCMV}^{-} \mathrm{HP}$ mammary carcinoma, which may explain the role of Grb2 in virus infected cell interactions, and this may due to the critical role of Grb2 in cell cycle progression and oncogenic pathways.

\section{CONCLUSION}

Due to the overexpression of Grb2 in $\mathrm{HCMV}^{+} \mathrm{IBC}$ and in HP breast cancer patients may marks Grb2 is an important target for IBC treatment strategy along with antiviral therapy. Additional studies are required to know the exact role of Grb2 and its downstream signaling pathway in $\mathrm{HCMV}^{+} \mathrm{IBC}$.

\section{ACKNOWLEDGMENTS}

Authors are supported by Avon Foundation-USA (MMM), Cairo University Scientific Research Sector, Giza, Egypt (SAI and MMM).

\section{REFERENCES}

1. Omar S, Khaled H, Gaafar R et al. (2003): Breast cancer in Egypt: a review of disease presentation and detection strategies. East Mediterr Health J., 9(3): 448-463.

2. Hance KW, Anderson WF, Devesa SS et al. (2005): Trends in inflammatory breast carcinoma incidence and survival: the surveillance, epidemiology, and end results program at the National Cancer Institute. J Natl Cancer Inst., 97(13): 966-975.

3. Schairer C, Brown LM, and Mai PL (2011): Inflammatory breast cancer: high risk of contralateral breast cancer compared to comparably staged noninflammatory breast cancer. Breast Cancer Res Treat, 129(1): 117-124.

4. Dawood S and Cristofanilli M (2011): Inflammatory breast cancer: what progress have we made? Oncology (Williston Park), 25(3): 264-273.

5. Schairer C, Soliman AS, Omar S et al. (2013): Assessment of diagnosis of inflammatory breast cancer cases at two cancer centers in Egypt and Tunisia. Cancer Med., 2(2): 178-184. 
Incidence of Human Cytomegalovirus in Breast Carcinoma Tissues...

6. Giubellino A, Burke TR and Bottaro DP (2008): Grb2 signaling in cell motility and cancer. Expert Opin Ther Targets, 12(8): 1021-1033.

7. Giubellino A, Shi ZD, Jenkins LM et al. (2008): Selectivity and mechanism of action of a growth factor receptor-bound protein $2 \mathrm{SRC}$ homology 2 domain binding antagonist. J Med Chem., 51(23): 7459-7468.

8. Alibek K, Kakpenova A, Mussabekova A et al. (2013): Role of viruses in the development of breast cancer. Infect Agent Cancer, 8(32): 1-6.

9. Landais I and Nelson JA (2013): Functional genomics approaches to understand cytomegalovirus replication, latency and pathogenesis. Curr Opin Virol., 3(4): 408-415.

10. Reyda S, Tenzer S, Navarro $P$ et al. (2014): The tegument protein pp65 of human cytomegalovirus acts as an optional scaffold protein that optimizes protein uploading into viral particles. J Virol., 88(17): 9633-9646.

11. Varnum SM, Streblow DN, Monroe ME et al. (2004): Identification of proteins in human cytomegalovirus (HCMV) particles: the HCMV proteome. J Virol., 78(20): 10960-10966.

12. Mohamed MM, Al-Raawi D, Sabet SF et al. (2014): Inflammatory breast cancer: New factors contribute to disease etiology: A review. J Adv Res., 5(5): 525-536.

13. Zhang S, Zhou YH, Li L et al. (2010): Monitoring human cytomegalovirus infection with nested PCR: comparison of positive rates in plasma and leukocytes and with quantitative PCR. Virol J., 7: 73.

14. El-Shinawi M, Mohamed HT, Abdel-Fattah HH et al. (2016): Inflammatory and non-inflammatory breast cancer: a potential role for detection of multiple viral DNAs in disease progression. Ann Surg Oncol., 23(2): 494-502.

15. Ijaz M, Shahbaz M, Jiang W et al. (2017): Oncogenic role of Grb2 in breast cancer and Grb2 antagonists as therapeutic drugs. Canc Therapy \& Oncol Int J., 3(4): 1-7.

16. Li LY, Li EM, Wu ZY et al. (2014): Overexpression of GRB2 is correlated with lymph node metastasis and poor prognosis in esophageal squamous cell carcinoma. Int $\mathbf{J}$ Clin Exp Pathol., 7(6): 3132-3140.

17. Toki MI, Carvajal-Hausdorf DE, Altan M et al. (2016): EGFR-Grb2 protein colocalization is a prognostic factor unrelated to overall egfr expression or EGFR mutation in lung adenocarcinoma. J Thorac Oncol, 11(11): 1901-1911.

18. Walter RF, Werner R, Vollbrecht C et al. (2016): ACTB, CDKN1B, GAPDH, GRB2, RHOA and SDCBP were identified as reference genes in neuroendocrine lung cancer via the nCounter Technology. PLoS One, 11(11): 111.

19. Yang L, Wen Y, Lv G et al. (2017): alpha-Lipoic acid inhibits human lung cancer cell proliferation through Grb2mediated EGFR downregulation. Biochem Biophys Res Commun., 494(1-2): 325-331.

20.Liang C, Xu Y, Ge H et al. (2017): miR-564 inhibits hepatocellular carcinoma cell proliferation and invasion by targeting the GRB2-ERK1/2-AKT axis. Oncotarget, 8(64): 107543-107557.

21. Chen J, Zhang N, Wen J et al. (2017): Silencing TAK1 alters gene expression signatures in bladder cancer cells. Oncol Lett., 13(5): 2975-2981.

22.Ijaz M, Wang F, Shahbaz M et al. (2018): The role of Grb2 in cancer and peptides as Grb2 antagonists. Protein Pept Lett., 24(12): 1084-1095.

23. Kozer N, Barua D, Henderson C et al. (2014): Recruitment of the adaptor protein Grb2 to EGFR Tetramers. Biochemistry, 53(16): 2594-2604.

24. Plummer M, de Martel C, Vignat J et al. (2016): Global burden of cancers attributable to infections in 2012: a synthetic analysis. Lancet Glob Health, 4(9): e609-e616.

25. Chen Z, Kolokoltsov AA, Wang J et al. (2012): GRB2 interaction with the ecotropic murine leukemia virus receptor, mCAT-1, controls virus entry and is stimulated by virus binding. Journal of virology, 86(3): 1421-1432.

26. Gannon OM, Antonsson A, Bennett IC et al. (2018): Viral infections and breast cancer - A current perspective. Cancer Lett., 420: 182-189.

27. Baryawno N, Rahbar A, Wolmer-Solberg $\mathbf{N}$ et al. (2011): Detection of human cytomegalovirus in medulloblastomas reveals a potential therapeutic target. J Clin Invest., 121(10): 4043-4055.

28. Pasquereau S, Al Moussawi F, Karam W et al. (2017): Cytomegalovirus, macrophages and breast cancer. Open Virol J., 11: 15-27.

29. Touma J, Rahbar A, Davoudi B et al. (2018): Abstract 4222: The prognostic impact of human cytomegalovirus infection in breast cancer. Cancer Research, 78:13 .

30.Gibson W (2008): Structure and formation of the cytomegalovirus virion. Curr Top Microbiol Immunol., 325: 187-204.

31. Cavignac Y, Lieber D, Laib Sampaio K et al. (2015): The cellular proteins Grb2 and DDX3 are increased upon human cytomegalovirus infection and Act in a proviral fashion. PLoS One, 10(6): 1-15.

32. Strunk U, Ramos DG, Saffran HA et al. (2016): Role of herpes simplex virus 1 VP11/12 tyrosine-based binding motifs for Src family kinases, p85, Grb2 and Shc in activation of the phosphoinositide 3-kinase-Akt pathway. Virology, 498: 31-35.

33. Macdonald A, Crowder K, Street A et al. (2004): The hepatitis C virus NS5A protein binds to members of the Src family of tyrosine kinases and regulates kinase activity. J Gen Virol., 85(3): 721-729.

34. Rom S, Pacifici M, Passiatore G et al. (2011): HIV-1 Tat binds to SH3 domains: cellular and viral outcome of Tat/Grb2 interaction. Biochim Biophys Acta, 1813(10): 1836-1844.

35. Rahbar A, Touma J, Costa H et al. (2017): Low expression of estrogen receptor-alpha and progesterone receptor in human breast cancer tissues is associated with high-grade human cytomegalovirus protein expression. Clin Breast Cancer, 17(7): 526-535. 